\title{
CHARACTERISTICS OF PERSONAL VALUE-MEANING SYSTEMS OF LATVIAN YOUTHS IN 1998, 2005, 2010 AND 2015: A COMPARATIVE STUDY
}

\author{
Jel̦ena L,evina \\ Kristīne Mārtinsone \\ Sandra Mihailova \\ Ilona Gintere \\ Rīga Stradiņš University, Latvia
}

\begin{abstract}
Research of personal values is one of the most important tasks in the context of social and economic changes of the society. The purpose of this research was to compare the values and the level of disintegration of personal value-meaning systems of Latvian youths in different periods of socio-economic development of Latvian society. The research was conducted in 1998 and repeated in 2005, 2010 and in 2015. All participants were students of $11^{\text {th }}$ or $12^{\text {th }}$ grade. To provide a measure of value-meaning systems the M. Rokeach technique modified by E.B. Fantalova was used. The results revealed that there were differences in ratings of importance and attainability of values as well as in levels of discrepancy between importance and attainability of values of Latvian youths in different periods of socioeconomic development of Latvian society.
\end{abstract}

Keywords: attainability of value, discrepancy between importance and attainability of value, importance of value, personal value-meaning system, values.

\section{Introduction}

Values research is recognized as one of the most important themes in the field of psychology. Personal values determine life choices, decisions and actions. Values are conceptions of the desirable that influence the way people select action and evaluate events (Schwartz \& Bilsky, 1987). Values are acquired during the process of personality development and do change under the influence of various events and life experience (Enggele, 2015).

Research of personal values is topical during the period when the society endures transitions in its development, when social, economic, political and cultural changes require from an individual a reconsideration and revaluation of values. Especially actual is the investigation of values during the late adolescence and youth when an individual's personal and professional selfdetermination and identity are the main developmental tasks. Disintegration of the personal value-meaning system is one of the major factors, which can influence the ability of young men to determine life goals as well as their psychological health in general. 
During the last two decades, Latvian society endured certain transitions such as the economic crisis, joining the EU, the introduction of the euro, changes in the labour market and labour migration, changes in the higher education sector and student migration. All these changes could affect valuemeaning systems of Latvian youths. Thus, the purpose of this research is to determine whether there are differences in personal value-meaning systems of Latvian youths in different periods of socio-economic development of Latvian society.

\section{The concept of personal values and value-meaning systems}

Schwartz and Bilsky (Schwartz \& Bilsky, 1987, 1990), integrating features from many existing definitions of values, defined values to be concepts or beliefs, pertaining to desirable end states or behaviors (modes of conduct), that transcend specific situations, guide selection or evaluation of behavior, people and events, and are ordered by relative importance.

Sets of values form value systems. Researchers (e.g. Salikhova, 2015a, 2015b) distinguish two main parameters, which characterize an individual's personal value-meaning system, - substantial and dynamic. The first important parameter of values is their substantive content. Respectively, according to the content of values, classifications of types of values were developed (e.g. Allport et al., 1960; Rokeach, 1973; Schwartz, 1992). Values are hierarchically organized (Cieciuch et. al., 2014; Schwartz et. al., 2012; Rokeach, 1973). The dynamic side of a person's value-meaning sphere refers to the relation of personality existential expectations and actual life situation (e.g. Salikhova, 2015a, 2015b). Fantalova (Фанталова, 2001) hypothesized that one of the most important determinants of the motivational personality sphere was the ratio of value and measure of its attainability in life. The state when the certain value is important, but not attainable, is defined as a state of the deep inner conflict. The state when the value is attainable, but not so important, is defined as the state of inner meaning vacuum. The discrepancy of importance and attainability of values is the main indicator of disintegration of the personal value-meaning system. Thus, the content and the level of discrepancy of importance and attainability of values are two main characteristics of an individual's personal value-meaning system.

\section{Youths' values}

In recent decades researchers have increasingly focused on youths' values. Substantial and / or dynamic parameters of personal value-meaning systems of youths in connection to social, economic, politic, cultural factors were investigated worldwide (Karvonen et al., 2012; Lan, 2009; Likitapiwat et al., 2015; Maercker et al., 2015; Meral, 2000; Petrov, 2008; Salikhova, 2015a). 
Youths' values were also investigated in Latvia (Austruma, 2012; Izglìtības un zinātnes ministrija, 2013; Jirgena \& Mārtinsone, 2007; Karpova, 1994; Koroleveva et al., 1999; Lūse, 2001; Šteinberga \& Tunne, 1999; Tunne, 1997). Jirgena (now Mihailova) and Martinsone (Jirgena \& Mārtinsone, 2007) in their research of Latvian youth's values in 1998 and in 2005 concluded that the values of Latvian youth whose childhood passed during the times of Socialism and the times of National Awakening, did not differ. They found that the most important values in both samples were love and good and reliable friends. Very similar results were obtained in the research conducted in 1994 by Karpova (Karpova, 1994), who also found that the most important values of Latvian students were good and reliable friends, love, health and happy family life. However, Jirgena and Martinsone (Jirgena \& Mārtinsone, 2007) identified some tendencies of changes of personal value-meaning systems of Latvian youths. They reported that the ratings of importance of such values as self-confidence and cognition were higher in 1998 comparing with 2005, while the ratings of health value were higher in 2005 .

Recently, Austruma (Austruma, 2012) conducted the research of values, which were acquired by young people in the modern consumer society in Latvia. She reported that young people's values in the consumer society reflect a collectively-fixed experience and the goal of the society that is promoted by the dominant post-modern consumer society. Austruma found that the prior values, chosen by young people from all culture-historical regions of Latvia, were family, friends, health, education, love, career and freedom.

In the research of Latvian youth's values, conducted in 2012/2013 (Izglìtības un zinātnes ministrija, 2013), it was found that Latvian youth most often identified as the more significant such values as cozy house, stable job, interesting job, happy life with a partner, profession which allows to earn good money, good education, ability to give own children a secure future.

Examination of the existing literature allows to conclude that such values as, for example, family, friends, love appear consistently important for Latvian youths. On the other hand, youths' values are also modified and reflect the experience of the social community's life.

\section{The present study}

Previous investigations have mainly focused on substantial parameters of personal value-meaning systems of youths. Less is known about dynamic parameters of personal value-meaning systems. There is also a lack of comparative studies, which are focused on differences in personal valuemeaning systems of Latvian youths in different periods of socio-economic development of Latvian society. Thus, in the current study there are three research questions: are there any differences (1) in ratings of importance of values and (2) in ratings of attainability of values as well as (3) in the level of 
discrepancy between importance and attainability of values of Latvian youths in different periods of socio-economic development of Latvian society?

\section{Methodology}

For measurement of importance and attainability as well as discrepancy between importance and attainability of values, the M. Rokeach (Rokeach, 1973) technique modified by E.B. Fantalova (Фанталова, 2001) was used. The Latvian version of the instrument was developed by S. Jirgena (now Mihailova) (Jirgena, 1999). The research participants received the list of twelve terminal values and two tables of all possible pairs of values. In the first table in each pair of values students had to mark the more important value, in the second - the more attainable value. Importance scores (I) were computed as the number of cases when a value was chosen as a more important, and attainability scores (A) - as the number of cases when a certain value was marked as a more attainable. The index of discrepancy $\left(\mathrm{R}_{\mathrm{I}-\mathrm{A}}\right)$ between importance and attainability was computed as a total difference of importance and attainability for all values $(\Sigma[\mathrm{I}-\mathrm{A}])$.

First time the research was conducted in 1998 and then was repeated in 2005, 2010 and in 2015. All participants were students of $11^{\text {th }}$ or $12^{\text {th }}$ grade from Riga secondary schools (aged between 16 and 19 years). The sample of the study in 1998 consisted of 115 participants ( $42.6 \%$ males, $57.4 \%$ females). In 2005 the sample consisted of 79 participants ( $17.7 \%$ males, $82.3 \%$ females). 82 students took part in the research in 2010 (32.9\% males, $67.1 \%$ females). At last, in 2015 the sample consisted of 144 participants $(39.6 \%$ males, $60.4 \%$ females).

\section{Results}

In order to determine whether there were differences in students' ratings of importance and attainability of values as well as in levels of discrepancy between importance and attainability of values in 1998, 2005, 2010 and 2015 the Kruskal-Wallis H test was used.

\section{Results of the comparison of the importance of values}

Descriptive statistics for the index of importance of values and the results of the comparative analysis are presented in Table 1.

The Kruskal-Wallis $\mathrm{H}$ test showed that there was a statistically significant difference in students' ratings of the importance of the following values: health $(p=.00)$, interesting job $(p=.05)$, love $(p=.00)$, good and reliable friends $(p=.00)$, self-confidence $(p=.00)$, cognition $(p<.05)$ and creativity $(p=.001)$. The pairwise comparisons were conducted using the Mann-Whitney U test. 
Table 1. The comparison of the importance of values

\begin{tabular}{|c|c|c|c|c|c|c|}
\hline \multirow[b]{3}{*}{ Values } & \multicolumn{4}{|c|}{ The research year } & \multirow[b]{3}{*}{$\chi^{2}$} & \multirow[b]{3}{*}{$p$} \\
\hline & 1998 & 2005 & 2010 & 2015 & & \\
\hline & $\begin{array}{l}M d n \\
(I Q R)\end{array}$ & $\begin{array}{l}M d n \\
(I Q R)\end{array}$ & $\begin{array}{l}M d n \\
(I Q R)\end{array}$ & $\begin{array}{l}M d n \\
(I Q R)\end{array}$ & & \\
\hline Active life & $3(2-5)$ & $4(2-5)$ & $4(2-5)$ & $4(2-5)$ & 1.78 & .618 \\
\hline Health & $6(4-8)$ & $7(5-10)$ & $7(5-10)$ & $\begin{array}{c}8(6- \\
10.75)\end{array}$ & 27.40 & .000 \\
\hline Interesting job & $5(4-7)$ & $5(4-6)$ & $5(4-6)$ & $4(3-6)$ & 9.34 & .025 \\
\hline Beauty of nature and art & $2(1-3)$ & $2(1-3)$ & $2(1-3)$ & $1(0-4)$ & 3.56 & .313 \\
\hline Love & $8(7-10)$ & $9(7-10)$ & $9(7-10)$ & $7(5.25-9)$ & 19.66 & .000 \\
\hline Material welfare & $6(4-8)$ & $7(4-8)$ & $7(4-8)$ & $6(4-8)$ & 6.48 & .090 \\
\hline Good and reliable friends & $8(6-9)$ & $8(6-9)$ & $8(6-9)$ & $\begin{array}{c}6.5(4.25- \\
8)\end{array}$ & 24.38 & .000 \\
\hline Self-confidence & $4(3-6)$ & $3(2-5)$ & $3(2-5)$ & $5(3-7)$ & 20.30 & .000 \\
\hline Cognition & $6(4-8)$ & $5(3-7)$ & $5(3-7)$ & $5(3-7)$ & 8.76 & .033 \\
\hline Freedom & $5(4-8)$ & $7(4-8)$ & $7(4-8)$ & $7(5-9)$ & 7.55 & .056 \\
\hline Happy family life & $9(6-10)$ & $9(8-10)$ & $9(8-10)$ & $9(6-10)$ & 1.48 & .687 \\
\hline Creativity & $2(0-4)$ & $1(0-3)$ & $1(0-3)$ & $2(1-4)$ & 17.40 & .001 \\
\hline
\end{tabular}

Health. It was found that there was a significant difference in students' ratings of importance of health value between respondents participated in the research (1) in 1998 and in $2005(z=-2.83, p<.01),(2)$ in 1998 and in 2010 $(z=-3.41, p=.001),(3)$ in 1998 and in $2015(z=-5.05, p=.000)$. The results indicated a statistically significant increase in the ratings of importance of health value for the students in 2005, 2010 and 2015 comparing with the students participated in the research in 1998.

Interesting job. The pairwise comparisons indicated that there was a significant difference in students' ratings of importance of interesting job between respondents participated in the research (1) in 1998 and in $2015(z=-$ 2.55, $p<.05)$, (2) in 2005 and in $2015(z=-2.47, p<.05)$. The results showed that the ratings of importance of interesting job were significantly higher for the students in 1998 and in 2005 than for the students in 2015.

Love. A statistically significant difference existed in students' ratings of importance of love between respondents participated in the research (1) in 1998 and in $2015(z=-3.31, p=.001),(2)$ in 2005 and in $2015(z=-4.03, p=.00)$. The ratings of importance of love were significantly higher for the students in 1998 and in 2005 than for the students in 2015.

Good and reliable friends. The Mann-Whitney $U$ test indicated a significant difference in students' ratings of importance of good and reliable friends between respondents participated in the research (1) in 1998 and in 2015 $(z=-4.29, p=.00),(2)$ in 2005 and in $2015(z=-3.82, p=.00)$, (3) in 2010 and in $2015(z=-2.20, p<.05)$. The results indicated a statistically significant decrease in the ratings of importance of good and reliable friends for the 
students in 2015 comparing with the students participated in the research in 1998, in 2005 as well as in 2010.

Self-confidence. It was found that there was a significant difference in students' ratings of importance of self-confidence between respondents participated in the research (1) in 1998 and in $2005(z=-2.30, p<.05)$, (2) in 2005 and in $2015(z=-4.04, p=.00)$, (3) in 2010 and in $2015(z=-3.24$, $p=.001)$. The results indicated a statistically significant decrease in the ratings of importance of self-confidence for the students in 2005 comparing with the students participated in the research in 1998, and a statistically significant increase in 2015 comparing with 2005 and 2010.

Cognition. The pairwise comparisons indicated that there was the only significant difference in students' ratings of importance cognition - between the group participated in the research in 1998 and between the group participated in the research in $2015(z=-2.67, p<.01)$. The results indicated a statistically significant decrease in the ratings of importance of this value for the students in 2015 comparing with the students participated in the research in 1998.

Creativity. There was a significant difference in students' ratings of importance of creativity between respondents participated in the research (1) in 1998 and in $2010(z=-2.74, p<.01)$, (2) in 1998 and in $2015(z=-2.21$, $p<.05)$, (3) in 2005 and in $2010(z=-3.43, p=.001)$, (4) in 2005 and in 2015 $(z=-3.19, p=.001)$. The results indicated a statistically significant increase in the ratings of importance of creativity for the students in 2010 and 2015 comparing with the students participated in the research in 1998 and in 2005.

\section{Results of the comparison of the attainability of values}

Descriptive statistics for the index of attainability of values and the results of the comparative analysis are presented in Table 2. The Kruskal-Wallis H test showed that there was a statistically significant difference in students' ratings of the attainability of the following values: active life $(p=.00)$, health $(p=.05)$, beauty of nature and art $(p=.01)$, love $(p=.05)$, good and reliable friends $(p=.00)$, cognition $(p=.00)$, happy family life $(p=.05)$ and creativity $(p=.05)$. For these values the follow-up pairwise comparisons (using the Mann-Whitney $\mathrm{U}$ test) were completed.

Active life. The pairwise comparisons indicated that there was a significant difference in students' ratings of attainability of active life between respondents participated in the research (1) in 1998 and in $2015(z=-4.40, p=.00)$, (2) in 2010 and in $2015(z=-2.76, p<.01)$, (3) in 2010 and in $2015(z=-2.82$, $p<.01)$. The results showed that the ratings of attainability of active life were significantly higher for the students in 2015 than for the students in 1998, 2005 and 2010 . 
Table 2. The comparison of the attainability of values

\begin{tabular}{|c|c|c|c|c|c|c|}
\hline \multirow[b]{3}{*}{ Values } & \multicolumn{4}{|c|}{ The research year } & \multirow[b]{3}{*}{$\chi^{2}$} & \multirow[b]{3}{*}{$p$} \\
\hline & 1998 & 2005 & 2010 & 2015 & & \\
\hline & $\begin{array}{l}M d n \\
(I Q R)\end{array}$ & $\begin{array}{l}M d n \\
(I Q R)\end{array}$ & $M d n(I Q R)$ & $M d n(I Q R)$ & & \\
\hline Active life & $6(5-8)$ & $7(6-8)$ & $7(5-9)$ & $8(6-10)$ & 22.26 & .000 \\
\hline Health & $5(3-7)$ & $3(1-6)$ & $\begin{array}{c}5(2.75- \\
6.25)\end{array}$ & $4(2-6)$ & 9.10 & .028 \\
\hline Interesting job & $5(4-7)$ & $5(4-7)$ & $6(4-7)$ & $5.5(4-7)$ & 1.05 & .790 \\
\hline Beauty of nature and art & $7(3-9)$ & $8(5-10)$ & $6(3-9)$ & $\begin{array}{c}8(5.25- \\
10)\end{array}$ & 15.31 & .002 \\
\hline Love & $5(2-7)$ & $4(2-7)$ & $4(2-6)$ & $3(2-5)$ & 9.86 & .020 \\
\hline Material welfare & $3(1-5)$ & $3(2-6)$ & $4(2-6)$ & $3(2-5)$ & 7.18 & .066 \\
\hline Good and reliable friends & $6(4-8)$ & $7(4-9)$ & $6(3-8)$ & $4(3-6)$ & 23.08 & .000 \\
\hline Self-confidence & $6(4-8)$ & $6(4-8)$ & $6(3.75-7)$ & $5(4-7)$ & 6.59 & .086 \\
\hline Cognition & $8(6-10)$ & $9(7-10)$ & $7(5-9)$ & $7(5-9)$ & 26.74 & .000 \\
\hline Freedom & $6(4-9)$ & $7(4-8)$ & $5(4-8)$ & $6(4-8)$ & 3.33 & .344 \\
\hline Happy family life & $2(1-5)$ & $3(1-6)$ & $4(1-6)$ & $3(2-5)$ & 9.97 & .019 \\
\hline Creativity & $5(2.75-8)$ & $5(2-8)$ & $5(2-8)$ & $7(3-9)$ & 8.46 & .037 \\
\hline
\end{tabular}

Health. The Mann-Whitney $U$ test indicated a significant difference in students' ratings of attainability of health between respondents participated in the research (1) in 1998 and in $2005(z=-2.75, p<.01),(2)$ in 2005 and in 2010 $(z=-2.06, p<.05)$. The results indicated a statistically significant decrease in the ratings of attainability of health value for the students in 2005 comparing with 1998 and a significant increase for the students in 2010 comparing with 2005.

Beauty of nature and art. The results of the pairwise comparisons indicated that there was a significant difference in students' ratings of attainability of beauty of nature and art between respondents participated in the research (1) in 1998 and in $2015(z=-2.59, p=.01),(2)$ in 2005 and in 2010 $(z=-2.58, p<.01),(3)$ in 2010 and in $2015(z=-3.46, p=.001)$. The ratings of attainability of this value were significantly lower for the students in 2010 comparing with 2005 and higher for the students in 2015 than for the students in 1998 as well as in 2010.

Love. A statistically significant difference existed in students' ratings of attainability of love between respondents participated in the research (1) in 1998 and in $2015(z=-2.96, p<.01),(2)$ in 2005 and in $2015(z=-2.00, p<.05)$. The results indicated a statistically significant decrease in the ratings of attainability of this value for the students in 2015 comparing with the students participated in the research in 1998 and in 2005.

Good and reliable friends. It was found that there was a significant difference in students' ratings of attainability of this value between respondents participated in the research (1) in 1998 and in $2015(z=-3.89, p=.00)$, (2) in 
2005 and in $2015(z=-3.69, p=.00)$, (3) in 2010 and in $2015(z=-3.41$, $p=.001)$. The ratings of attainability of this value were significantly lower for the students in 2015 comparing with the students in 1998, 2005 and 2010.

Cognition. A statistically significant difference existed in students' ratings of attainability of cognition between respondents participated in the research (1) in 1998 and in $2010(z=-2.97, p<.01)$, (2) in 1998 and in $2015(z=-3.55$, $p=.00),(3)$ in 2005 and in $2010(z=-3.67, p=.00)$, (4) in 2005 and in 2015 $(z=-4.18, p=.00)$. The results indicated a statistically significant decrease in the ratings of attainability of this value for the students in 2010 and in 2015 comparing with the students participated in the research in 1998 and in 2005.

Happy family life. It was found there was a significant difference in students' ratings between respondents participated in the research (1) in 1998 and in $2010(z=-2.85, p<.01)$, (2) in 1998 and in $2015(z=-2.41, p<.05)$. The ratings of attainability of happy family life were significantly higher in 2010 and in 2015 comparing with the students' ratings in 1998.

Creativity. A statistically significant difference existed in students' ratings between respondents participated in the research (1) in 1998 and in 2015 $(z=-2.32, p<.05),(2)$ in 2005 and in $2015(z=-2.15, p<.05)$, (3) in 2010 and in $2015(z=-2.21, p<.05)$. The ratings of attainability of creativity were significantly higher in 2015 comparing with the students' ratings in 1998, in 2005 and in 2010.

Results of the comparison of levels of discrepancy between importance and attainability of values

Descriptive statistics for the level of discrepancy between importance and attainability of values and the results of the comparative analysis are presented in Table 3.

Table 3. The comparison of the level of discrepancy between importance and attainability of values

\begin{tabular}{cccccccc}
\hline & \multicolumn{9}{c}{ The research year } & & \\
\cline { 2 - 6 } & $\mathbf{1 9 9 8}$ & $\mathbf{2 0 0 5}$ & $\mathbf{2 0 1 0}$ & $\mathbf{2 0 1 5}$ & & \\
& $M d n$ & $M d n$ & $M d n$ & $M d n$ & $\chi^{2}$ & $p$ \\
& $(I Q R)$ & $(I Q R)$ & $(I Q R)$ & $(I Q R)$ & & \\
\hline The level of discrepancy & $42(31-54)$ & $49(35-56)$ & $39(26-54)$ & $50(36-60)$ & 16.00 & .001 \\
\hline
\end{tabular}

The Kruskal-Wallis $\mathrm{H}$ test showed that there was a statistically significant difference in levels of discrepancy between importance and attainability of values $(p=.001)$. The pairwise comparisons were conducted using the MannWhitney $U$ test. A significant difference in levels of discrepancy between importance and attainability of values existed between respondents participated in the research (1) in 1998 and in $2015(\mathrm{z}=-3.01, \mathrm{p}<.01)$, (2) in 2005 and in $2010(\mathrm{z}=-2.09, \mathrm{p}<.05),(3)$ in 2010 and in $2015(\mathrm{z}=-3.41, \mathrm{p}=.001)$. The level of discrepancy between importance and attainability of values has decreased in 
2010 comparing with 2005, and it has increased in 2015 comparing with results obtained in 2010 and in 1998.

\section{Conclusions}

Initially the study was conducted in 1998 among the youths whose childhood passed during the times of Socialism. The study was repeated in 2005 (in the period of economic growth and prosperity, among the youths whose childhood passed during the times of National Awakening), then in 2010 (in the post-crisis period), and in 2015 (in the period when with the support of the EU youths' opportunities of self-realization are expanded).

First, the importance of such values as health and creativity increased, while the importance of such values as love and good and reliable friends as well as interesting job and cognition decreased. The importance of health increased in 2015, 2010 and 2005 comparing with 1998. The importance of creativity increased in 2015 and 2010 comparing with 2010 and 1998. The importance of interesting job and love decreased in 2015 comparing with 2005 and 1998. The importance of good and reliable friends decreased in 2015 comparing with 2010, 2005 and 1998. The importance of cognition decreased in 2015 comparing with 1998. In addition, there were also some changes in ratings of the importance of self-confidence. The importance of self-confidence decreased in 2005 comparing with 1998 and increased in 2015 comparing with 2005 and 2010.

Second, the attainability of such values as active life and creativity as well as happy family life increased, while the attainability of such values as love and good and reliable friends, as well as cognition decreased. The attainability of active life and creativity increased in 2015 comparing with 2010, 2005 and 1998. The attainability of happy family life increased in 2010 and in 2015 comparing with 1998. At the same time, the attainability of love decreased in 2015 comparing with 1998 and 2005. The attainability of good and reliable friends decreased in 2015 comparing with 1998, 2005 and 2010. The attainability of cognition decreased in 2010 and 2015 comparing with 1998 and 2005. There were also some changes in ratings of attainability of health and beauty of nature and art. The attainability of health decreased in 2005 comparing with 1998, and increased in 2010 comparing with 2005. The attainability of beauty of nature and art decreased in 2010 comparing with 2005, and increased in 2015 comparing with 1998 and 2010.

Some patterns of changes of personal value-meaning systems of Latvian youths (e.g., the observed increase of the importance of creativity and the revealed decrease of the importance of love and friends) allows to propose that the values of Latvian youth underwent certain changes toward a more competitive and individualistic orientation. 
Third, the level of discrepancy between importance and attainability of values has decreased in the post-crisis period (in 2010) comparing with the results obtained in the period of economic growth and prosperity (in 2005). However, it has increased in the period of expanding opportunities for selfrealization (in 2015) comparing with the results obtained in the post-crisis period (in 2010) and in the period of stabilizing of socially economic state of society (in 1998). Such findings allows to propose that the expansion of opportunities make some values more attainable, however, not necessary important, and as a result, can cause meaning vacuums and internal emptiness.

The obtained results supported the expectation that there should be differences in ratings of importance and attainability of values as well as in levels of discrepancy between importance and attainability of values of Latvian youths in different periods of socio-economic development of Latvian society.

The paper was supported by the National Research Program 5.2. "Economic Transformation, Smart Growth, Governance and Legal Framework for the State and Society for Sustainable Development - a New Approach to the Creation of a Sustainable Learning Community (EKOSOC-LV)"

\section{References}

Allport, G. W., Vernon, P. E., \& Lindzey, G. (1960). A study of values. Boston: Houghton Mifflin.

Austruma, S. (2012). Jauniešu vērtibas patērētajsabiedribā Latvija- Promocijas darba kopsavilkums. Rēzekne: Rēzeknes Augstskola.

Cieciuch, J., Davidov, E., Vecchione, M., \& Schwartz, S. H. (2014). A hierarchical structure of basic human values in a third-order confirmatory factor analysis. Swiss Journal of Psychology, 73(3), 177-182.

Eņgéele, I. (2015). Indivīda vērtības. No: K. Mārtinsone, A. Miltuze (Red.), Psihologija. Rīga: Zvaigzne ABC, 99-107.lpp.

Izglītības un zinātnes ministrija (2013). Jauniešu iespēju, attieksmju un vērtību pētījums. Piejams: http://izm.izm.gov.lv/upload_file/jaunatne/IZM_EKCYP_Jauniesu_aptauja_E xcolo_2013.pdf.

Jirgena, S. (1999). Jauniešu pašizjūta un adiktīvas uzvedības izvēle. Promocijas darbs. Rīga: LU.

Jirgena S., Mārtinsone K. (2007). Vērtību hierarhija: jauniešu salīdzinošais vērtējums 1998. un 2005.gadā. Sabiedrība un kultūra. Rakstu krājums IX. A.Medveckis (Sast.). Liepāja: LiePA, 2007, 112-119. lpp.

Karpova, Ā. (1994). Personiba un individuatais stils. Rìga: Latvijas Universitāte.

Karvonen, S., Young, R., West, P., \& Rahkonen, O. (2012). Value orientations among late modern youth - a cross-cultural study. Journal of Youth Studies, 15 (1), 33-52.

Lan, J. (2009). The impact of globalization on the values of contemporary Chinese youth, Journal of Youth Studies, 12, 12-16.

Likitapiwat, T., Sereetrakul, W., \& Wichadee, S. (2015). Examining materialistic values of university students in Thailand.International Journal of Psychological Research, 8 (1), 109-118.

Koroljeva I., Rungule R., Sebre S., Trapenciere I. (1999). Latvijas jaunatnes sociologisks portrets. Rìga: Latvijas Universitātes Filozofijas un sociologijas institūts. 
Lūse, D. (2001). Individuālisma un kolektīvisma vērtību orientācijas Latvijas jauniešu vidū. IT laikmets: jaunatne un sociālās izmainas. Rīga: FSI, VJIC, 249-255.lpp.

Maercker, A., Zhang, X.C.,Gao, Z., Kochetkov, Y., Lu, S., Sang, Z., Yang, S., Schneider, S., Margraf, J. (2015). Personal value orientations as mediated predictors of mental health: A three-culture study of Chinese, Russian, and German university students. International Journal of Clinical and Health Psychology, 15, 8-17

Meral, C. (2000). Change in value orientations of Turkish youth from 1989 to 1995. Journal of Psychology, 134 (3), 297-305.

Petrov, A.V. (2008). The value preferences of young people. Russian Education and Society, $50(9), 53-67$.

Rokeach, M. (1973). The nature of human values. New York: Free Press.

Salikhova, N. (2015a). The comparison of substantial and dynamic parameters personal value-meaning systems of American and Russian university students, Review of European Studies, 7 (4), 117-123.

Salikhova, N. (2015b). The correlation of importance and attainability disparity in the personality value system with the meaningfulness of life. Review of European Studies, 7, (1), 141-147.

Schwartz, S. H. (1992). Universals in the content and structure of values: Theoretical advances and empirical tests in 20 countries. In M. Zanna (Ed.), Advances in experimental social psychology (Vol. 25, pp. 1-65). Orlando, FL: Academic.

Schwartz, S.H. \& Bilsky, W. (1987). Toward a universal psychological structure of human values. Journal of Personality and Social Psychology, 53, 550-562.

Schwartz, S. H. \& Bilsky, W. (1990). Toward a theory of the universal content and structure of values: Extensions and cross-cultural replications. Journal of Personality and Social Psychology, 58, 878-891.

Schwartz, S. H., Cieciuch, J., Vecchione, M., Davidov, E., Fischer, R., Beierlein, C., Ramos, A., Verkasalo, M., Lönnqvist, J.E., Demirutku, K., Dirilen-Gumus, Konty, M. (2012). Refining the theory of basic individual values. Journal of Personality and Social Psychology, 103, 663-688.

Šteinberga, A., Tunne, I., (1999). Jauniešu pašizjūta un vērtības. Rīga: RaKa.

Tunne, I. (1997). Studējošās jaunatnes vērtību orientācija Latvijā. Nepublicēta disertāija. Rīga: LU.

Фанталова Е.Б. (2001). Диагностика и психотерапия внутреннего конфликта. Самара: БАXPAX-M. 